\title{
Bacillus glucanolyticus, a New Species That Degrades a Variety of $\beta$-Glucans
}

\author{
BRIAN ALEXANDER AND FERGUS G. PRIEST* \\ Department of Brewing and Biological Sciences, Heriot Watt University, Edinburgh EHI 1HX, Scotland
}

\begin{abstract}
A new species, Bacillus glucanolyticus, is proposed for a group of facultatively anaerobic endospore-forming bacteria isolated from soil that hydrolyze various $\beta$-glucans, including carboxymethyl cellulose and pustulan. Of the 14 strains examined, 11 were phenotypically homogeneous, and five of these strains showed high levels of deoxyribonucleic acid (DNA) relatedness $(>68 \%)$ to a reference strain. Two pustulan-hydrolyzing strains were atypical, with low levels of DNA relatedness (52 to $57 \%$ ), and a third strain was not classified as $B$. glucanolyticus. $B$. glucanolyticus strains produce motile microcolonies similar to those of Bacillus alvei but can be distinguished from this taxon by several phenotypic characteristics and a higher DNA base composition (48 mol\%). B. glucanolyticus is similar to Bacillus circulans and related species; indeed, four strains were received as $B$. circulans, but distinctive phenotypic characteristics and low levels of DNA homology with $B$. circulans, Bacillus amylolyticus, Bacillus lautus, Bacillus pabuli, and Bacillus validus strains support its introduction as a new species. The type strain of $B$. glucanolyticus is strain $\operatorname{S93}\left(=\right.$ DSM $\left.5162^{\mathrm{T}}\right)$.
\end{abstract}

Members of the genus Bacillus secrete a variety of extracellular enzymes, including several types of $\beta$-glucanases (12). These enzymes are generally active on 1,4- $\beta$-linked (cellulose) and 1,3- $\beta$-linked (laminarin) polymers or mixed $1,4 / 1,3-\beta$-linked polymers $(1,3,15)$, but a class active on $1,6-\beta$-linked polymers, of which pustulan is an example, has been detected in Bacillus circulans (17). $\beta-1,6-$ Glucanases seem to be relatively rare, and, in a comprehensive numerical taxonomic study of the genus Bacillus, pustulan hydrolysis was associated with only 2 of the 49 clusters described (14). Both of these taxa contained bacteria previously labeled $B$. circulans. One (taxon 7) has since been shown to be identical to Bacillus pabuli, a species that was recently resurrected (7) to accommodate certain strains that had previously borne that name. The other (taxon 4) contained strains that were distinct from all other species, including those related to $B$. circulans. We propose that taxon 4 organisms should be given species status as Bacillus glucanolyticus.

\section{MATERIALS AND METHODS}

Strains and isolation conditions. The reference strains used in this study are shown in Table 1. Taxon 4 strains (14) were isolated from samples of garden and agricultural soils (strain designations beginning with $\mathrm{E}$ [see Table 3]) by incubating pasteurized $\left(80^{\circ} \mathrm{C}, 10 \mathrm{~min}\right)$ soil suspensions in nutrient broth (Oxoid Ltd., London, England) at $30^{\circ} \mathrm{C}$ in an anaerobic cabinet for 3 days. Samples were plated onto nutrient agar or nutrient agar containing tetracycline $(2 \mu \mathrm{g} / \mathrm{ml})$, and isolates producing motile microcolonies similar to those of Bacillus alvei were purified by replating. Strains were maintained in $20 \%$ glycerol at $-20^{\circ} \mathrm{C}$.

Identification of isolates. Strains were examined for 30 phenotypic characteristics and were identified by using a probabilistic method (13). Strains identified as members of taxon 4 were examined for pustulan hydrolysis by plating them onto nutrient agar containing $0.2 \%$ pustulan (Calbiochem-Behring, La Jolla, Calif.) and incubating the preparations aerobically for 5 days at $30^{\circ} \mathrm{C}$. The plates were flooded with ethanol and left at $4^{\circ} \mathrm{C}$. Pustulan hydrolysis was re-

\footnotetext{
* Corresponding author.
}

vealed as clear zones around colonies. Other tests included hydrolysis of carboxymethyl cellulose (medium viscocity; Sigma Chemical Co., St. Louis, Mo.), which was detected by plating strains onto nutrient agar containing $0.2 \%$ carboxymethyl cellulose and incubating them at $30^{\circ} \mathrm{C}$ for 5 days. The plates were acidified by flooding with $1 \mathrm{M} \mathrm{HCl}$ for 30 min; then the acid was decanted and replaced with ethanol. After incubation at $4^{\circ} \mathrm{C}$ for $16 \mathrm{~h}$, carboxymethyl cellulose hydrolysis was revealed as zones of clearing against an opaque background. All other test methods were based on those of Gordon et al. (4) and have been described previously (14).

DNA analyses. Deoxyribonucleic acid (DNA) was prepared from cultures grown overnight in nutrient broth by phenol extraction following lysis with lysozyme (16). Guanine-plus-cytosine $(G+C)$ contents were calculated from thermal denaturation points $\left(T_{m}\right)$ in $0.1 \times \mathrm{SSC}(1 \times \mathrm{SSC}$ is $0.15 \mathrm{M} \mathrm{NaCl}$ plus $0.015 \mathrm{M}$ sodium citrate) by using the following equation: $\mathrm{G}+\mathrm{C}$ content $=51.0+2.08\left(T_{m}\right.$ of unknown $-T_{m}$ of Escherichia coli) (11). DNA prepared from $E$. coli NCIMB 10213 (National Collection of Industrial and Marine Bacteria, Aberdeen, Scotland) was used as a standard and had a $T_{m}$ of $74.6^{\circ} \mathrm{C}$.

DNA concentrations were determined by using the diphenylamine assay (5) and salmon testis DNA (Sigma) as a standard.

Hybridization probe DNA was sheared by sonication to fragments of about 100 kilodaltons, denatured by heating $\left(100^{\circ} \mathrm{C}, 7 \mathrm{~min}\right)$, and, after rapid cooling, hybridized to random oligo primers (Amersham Corp., Arlington Heights, Ill.). A Klenow fragment (Boehringer Mannheim Biochemicals, Indianapolis, Ind.) was used to synthesize complementary DNA labeled with deoxycytidine $\left(5^{\prime}-\left[\alpha-{ }^{32} \mathrm{P}\right]\right.$ triphosphate $\left(3,000 \mathrm{Ci} / \mathrm{mmol}\right.$; Amersham) to a level of $1 \times 10^{6}$ to 3 $\times 10^{6} \mathrm{cpm} / \mu \mathrm{g}$ of DNA by using the procedure described by Feinberg and Vogelstein (2). Hybridizations were performed by the method of Seldin and Dubnau (18), using the slot blot system (Schleicher \& Schuell, Inc., Keene, N.H.), but reassociation was carried out at $42^{\circ} \mathrm{C}$ in $50 \%$ deionized formamide (equivalent to $20^{\circ} \mathrm{C}$ below the $T_{m}$; i.e., optimal conditions). Filters were washed in $6 \times$ SSC containing $0.1 \%$ sodium dodecyl sulfate until high and low spots could be detected with a geiger counter. Autoradiographs were ex- 
TABLE 1. Reference strains used in this study

\begin{tabular}{|c|c|c|}
\hline Taxon & Strain & Source $^{a}$ \\
\hline B. alvei & $\operatorname{DSM} 29^{\mathrm{T}}$ & DSM \\
\hline \multirow[t]{2}{*}{ B. amylolyticus } & NRRL-NRS-1136 & Nakamura \\
\hline & NRRL-B-142 & Nakamura \\
\hline B. circulans & DSM $11^{T}$ & DSM \\
\hline \multirow[t]{4}{*}{ Taxon $4^{b}$} & $\mathrm{~S} 103$ & $\begin{array}{l}\text { B. circulans, Norris, } \\
\text { B0319 }\end{array}$ \\
\hline & $\mathrm{S} 93^{\mathrm{T}}$ & $\begin{array}{l}\text { B. circulans, Norris, } \\
\mathrm{B} 0030^{\mathrm{T}}\end{array}$ \\
\hline & S94 & $\begin{array}{l}\text { B. circulans, Norris, } \\
\text { B0061 }\end{array}$ \\
\hline & S96 & $\begin{array}{l}\text { B. circulans, Norris, } \\
\text { B0197 }\end{array}$ \\
\hline B. lautus & NRRL-NRS-1171 & Nakamura \\
\hline \multirow[t]{3}{*}{ B. pabuli } & NRRL-NRS-924 & Nakamura \\
\hline & NRRL-B-745 & Nakamura \\
\hline & NRRL-B-14213 & Nakamura \\
\hline \multirow[t]{3}{*}{ B. validus } & NRRL-NRS- $1000^{\mathrm{T}}$ & Nakamura \\
\hline & NRRL-NRS-625 & Nakamura \\
\hline & NRRL-NRS-639 & Nakamura \\
\hline
\end{tabular}

a DSM, Deutsche Sammlung von Mikroorganismen, Braunschweig, Federal Republic of Germany; Nakamura, L. K. Nakamura, Northern Regional Research Laboratory, Peoria, Ill.; Norris, J. R. Norris, Cadbury Schweppes Ltd., Reading, United Kingdom.

${ }^{b}$ See reference 14

posed at $-20^{\circ} \mathrm{C}$ for 2 to $24 \mathrm{~h}$ by using X-Omat film (Eastman Kodak Co., Rochester, N.Y.). Levels of DNA homology were determined by cutting out the spots and counting bound radioactivity in $4 \mathrm{ml}$ of Cocktail $\mathrm{O}$ (British Drug Houses, Poole, United Kingdom). The counts were compared with counts from homologous reactions, and negative controls in which DNA from Aeromonas hydrophila (a gift from B. Austin, Department of Brewing and Biological Sciences, Heriot Watt University, Edinburgh, Scotland) were used. All experiments were run with at least four replicates.

\section{RESULTS AND DISCUSSION}

Phenotypic characteristics. Strains of taxon 4 were readily isolated from various soils. A low level of tetracycline was
TABLE 3. DNA relatedness and computer identification of reference strains and environmental isolates of $B$. glucanolyticus

\begin{tabular}{lllrrr}
\hline Strain & \multicolumn{1}{c}{ Identity } & $\begin{array}{c}\text { Willcox } \\
\text { proba- } \\
\text { bility }\end{array}$ & $\begin{array}{c}\text { SE of } \\
\text { taxonomic } \\
\text { distance }^{a}\end{array}$ & $\begin{array}{c}\text { \% DNA } \\
\text { relatedness } \\
\text { with strain } \\
\text { S93 }^{\text {Tb }}\end{array}$ & $\begin{array}{c}\text { Pustulan } \\
\text { hydro- } \\
\text { lysis }\end{array}$ \\
\hline S93 & B. glucanolyticus & 0.99 & 3.61 & 100 & + \\
S94 & B. glucanolyticus & 1.09 & -0.79 & $68(3.2)$ & + \\
S96 & B. glucanolyticus & 0.999 & 1.05 & $96(2.9)$ & + \\
S103 & B. glucanolyticus & 1.0 & -1.65 & $74(7.0)$ & + \\
E28 & B. glucanolyticus & 0.999 & 2.32 & $85(3.5)$ & + \\
E64 & B. glucanolyticus & 0.999 & 1.21 & $77(3.3)$ & + \\
E62 & B. glucanolyticus & 0.999 & 3.10 & - & + \\
E66 & B. glucanolyticus & 0.999 & 2.56 & - & + \\
E67 & B. glucanolyticus & 0.999 & 3.64 & - & + \\
E68 & B. glucanolyticus & 0.999 & 1.20 & - & + \\
E73 & B. glucanolyticus & 0.999 & 4.32 & - & + \\
E65 & Unidentified & 0.936 & 4.77 & $57(3.5)$ & + \\
E85 & Unidentified & 0.949 & 7.44 & $52(0.7)$ & + \\
E92 & Unidentified & 0.718 & 5.74 & - & + \\
\hline
\end{tabular}

${ }^{a}$ An Identity is defined as a Willcox probability greater than 0.95 with a standard error of taxonomic distance less than 7.0 (13).

${ }^{b}$ Mean for four experiments. The numbers in parentheses are standard deviations.

${ }^{c}$ - No homology data available for this strain.

an effective selective agent but in most cases was unnecessary. These environmental isolates and the strains from the original numerical classification study (14) had uniform characteristics that distinguished them from other species related to $B$. circulans (Table 2). In particular, anaerobic growth, the formation of motile microcolonies, a negative urease reaction, reduction of nitrate to nitrite, and pustulan hydrolysis were characteristic of strains of taxon 4 . These strains could be distinguished from $B$. alvei, the only other species producing motile microcolonies, by the Voges-Proskauer reaction, acid production from xylose, pustulan hydrolysis, and lack of indole formation. We propose the name $B$. glucanolyticus for these distinct strains; a description is given below.

Description of Bacillus glucanolyticus sp. nov. Bacillus glucanolyticus (gluc.an.o.lyt'i.cus. Gr. adj. glukos, sweet,

TABLE 2. Characters for distinguishing B. glucanolyticus from related species ${ }^{a}$

\begin{tabular}{|c|c|c|c|c|c|c|c|c|c|}
\hline Character & $\begin{array}{l}\text { B. glucano- } \\
\text { lyticus }\end{array}$ & B. alvei & $\begin{array}{l}\text { B. amyloly- } \\
\text { ticus }\end{array}$ & B. circulans & B. lautus & B. pabuli & B. validus & $\begin{array}{l}\text { B.alginoly- } \\
\text { ticus }\end{array}$ & $\begin{array}{l}\text { B. chrondro- } \\
\text { itinus }\end{array}$ \\
\hline \multicolumn{10}{|l|}{ Hydrolysis of: } \\
\hline Carboxymethyl cellulose & $++^{b}$ & + & - & - & + & + & - & $\mathrm{ND}^{c}$ & ND \\
\hline DNA & + & + & - & + & V & V & V & ND & ND \\
\hline Pustulan & + & - & - & - & - & + & - & ND & ND \\
\hline Urea & - & V & - & - & + & - & + & + & + \\
\hline \multicolumn{10}{|l|}{ Acid from: } \\
\hline L-Arabinose & $\mathrm{V}$ & - & + & + & V & V & - & + & + \\
\hline L-Rhamnose & - & - & $\mathrm{V}$ & + & + & + & + & + & + \\
\hline Sorbitol & - & - & - & + & - & - & + & - & - \\
\hline D-Xylose & + & - & + & + & + & + & V & + & + \\
\hline Growth in $5 \% \mathrm{NaCl}$ & + & + & V & + & + & V & - & - & - \\
\hline Nitrate reduced to nitrite & + & - & + & - & + & - & - & - & - \\
\hline Voges-Proskauer reaction & - & + & - & - & - & - & - & - & - \\
\hline Anaerobic growth & + & + & + & + & + & + & + & - & - \\
\hline Production of indole & - & + & - & - & - & - & - & - & - \\
\hline $\begin{array}{l}\text { Motile micro-colonies on } \\
\text { nutrient agar }\end{array}$ & + & + & - & - & - & - & - & - & - \\
\hline $\mathrm{G}+\mathrm{C}$ content $(\mathrm{mol} \%)$ & 48 & $44-46$ & 53 & $37-39$ & $50-52$ & $48-50$ & $53-54$ & $47-49$ & $47-48$ \\
\hline
\end{tabular}

${ }^{a}$ Data from this study and references 7 through 10 and 14 .

$b+$, More than $85 \%$ of the strains positive; - , less than $15 \%$ of the strains positive; $\mathrm{V}$, variable reaction.

c ND, Not determined. 
TABLE 4. Levels of DNA relatedness of B. glucanolyticus and other species in the B. circulans complex

\begin{tabular}{|c|c|c|c|c|c|}
\hline \multirow[b]{2}{*}{ Strain } & \multicolumn{5}{|c|}{$\%$ Reassociation with DNA from ${ }^{a}$ : } \\
\hline & $\begin{array}{l}\text { B. amylolyticus } \\
\text { NRRL-B-142 }\end{array}$ & $\begin{array}{l}\text { B. circulans } \\
\text { DSM } 11^{\mathrm{T}}\end{array}$ & $\begin{array}{l}\text { B. lautus } \\
\text { NRRL-NRS-1171 }\end{array}$ & $\begin{array}{c}\text { B. pabuli } \\
\text { NRRL-NRS- } 924^{\mathrm{T}}\end{array}$ & $\begin{array}{c}\text { B. validus } \\
\text { NRRL-NRS-639 }\end{array}$ \\
\hline \multicolumn{6}{|l|}{ B. amylolyticus } \\
\hline NRRL-B-142 & 100 & $14(1.6)$ & $31(3.4)$ & $38(10.7)$ & $4(1.0)$ \\
\hline NRRL-NRS-1136 & $98(2.8)$ & $15(7.0)$ & $30(6.8)$ & $50(4.0)$ & $6(0.7)$ \\
\hline B. circulans DSM $11^{\mathrm{T}}$ & $33(4.8)$ & 100 & $33(4.2)$ & $47(0)$ & $2(0.7)$ \\
\hline B. glucanolyticus $\mathrm{S} 93^{\mathrm{T}}$ & $14(2.6)$ & $15(6.5)$ & $34(4.6)$ & $20(3.6)$ & $2(3.7)$ \\
\hline B. lautus NRRL-NRS-1171 & $24(1.4)$ & $24(10.0)$ & 100 & $44(4.2)$ & $2(2.5)$ \\
\hline \multicolumn{6}{|l|}{ B. pabuli } \\
\hline NRRL-B-745 & $42(3.2)$ & $12(4.0)$ & $33(5.7)$ & $97(9.4)$ & $5(1.6)$ \\
\hline NRRL-B-14213 & $18(7.1)$ & $21(7.0)$ & $24(0.6)$ & $98(1.7)$ & $3(1.7)$ \\
\hline NRRL-NRS-924 ${ }^{\mathrm{T}}$ & $7(2.1)$ & $16(3.5)$ & $20(2.9)$ & 100 & $2(4.0)$ \\
\hline \multicolumn{6}{|l|}{ B. validus } \\
\hline NRRL-NRS-625 & $16(4.1)$ & $9(6.0)$ & $29(1.7)$ & $39(7.7)$ & $93(6.5)$ \\
\hline NRRL-NRS-639 & $2(1.7)$ & $20(1.0)$ & $31(5.2)$ & $41(7.6)$ & 100 \\
\hline NRRL-NRS-1000 ${ }^{\mathrm{T}}$ & $4(1.0)$ & $2(0.7)$ & $2(0)$ & $5(4.0)$ & $93(4.0)$ \\
\hline
\end{tabular}

${ }^{a}$ Reassociation values are means from four determinations; standard deviations are given in parentheses.

glucose; Gr. n. an, polymer; Gr. adj. lytos, dissolvable; M.L. adj. glucanolyticus, hydrolyzing glucose polymers). Cells are long (usually $>3.0 \mu \mathrm{m}$ ) and thin $(<0.9 \mu \mathrm{m})$ and produce oval terminal spores that markedly distend the sporangium. Colonies are flat, smooth, and opaque and are motile during growth on dry nutrient agar plates. Growth at pH 5.7. Growth at 17 to $37^{\circ} \mathrm{C}$ but not at 5 or $50^{\circ} \mathrm{C}$. Variable growth at $45^{\circ} \mathrm{C}$. Facultatively anaerobic. No gas is produced from glucose. Acid is produced from cellobiose, D-fructose, D-galactose, D-glucose, lactose, maltose, D-mannose, raffinose, salicin, sucrose, trehalose, and D-xylose. Acid is produced by most strains (including the type strain) from L-arabinose, glycerol, and mannitol. The $\mathrm{pH}$ in VogesProskauer broth is less than 5.5. Acid is not produced from dulcitol, erythritol, or sorbitol. All strains hydrolyze arbutin, carboxymethyl cellulose, esculin, DNA, pullulan, pustulan, ribonucleic acid, and starch. No strain hydrolyzes allantoin, chitin, elastin, lecithin, pectin, tyrosine, or urea. Most strains hydrolyze casein and gelatin and utilize citrate and succinate. Strains grow in the presence of $5 \% \mathrm{NaCl}$ but not in the presence of $10 \% \mathrm{NaCl}$ and are negative for indole production and the Voges-Proskauer reaction. The $\mathrm{G}+\mathrm{C}$ content of the DNA ranges from 48.3 to $48.6 \mathrm{~mol} \%$. $B$. glucanolyticus strains were isolated from soil by plating pasteurized suspensions onto nutrient agar.

The type strain is strain DSM $5162^{\mathrm{T}}(=$ NCIMB $12809=$ $\mathrm{S} 93$ ). The $\mathrm{G}+\mathrm{C}$ content of this strain is $49 \mathrm{~mol} \%$. The type strain conforms to the description given above.

Most environmental isolates showed high Willcox probabilities and low standard errors of taxonomic distance for $B$. glucanolyticus (Table 3 ) when a probabilistic identification scheme was used (13). This indicates a close match between the characteristics of an isolate and the characteristics of the taxon. Indeed, from our experience, a Willcox probability greater than 0.99 coupled with a standard error of taxonomic distance less than 4.0 indicates that an isolate matches the taxon description in all but one or two characters (13; unpublished data). If we adopt our normal criterion of a Willcox probability greater than 0.950 coupled with a standard error of taxonomic distance less than 7.0 as proof of positive identification, then 7 of the 10 environmental isolates and all 4 of the original strains can be confidently assigned to $B$. glucanolyticus. The three strains that showed low Willcox probabilities differed in 5 or 6 of the 30 characters and perhaps represent other species (see below).
Most strains of $B$. glucanolyticus exhibited high levels of DNA homology to strain $S 93^{\mathrm{T}}(\mathrm{T}=$ type strain), indicating that these organisms form a coherent genotypic group. It has been suggested that the minimum level of DNA homology within a species should be about $60 \%(6)$; therefore, most of the strains which we studied can be assigned to $B$. glucanolyticus. Two strains (strains E65 and E85) exhibited low Willcox probabilities and low levels of DNA homology with strain $\mathrm{S} 93^{\mathrm{T}}$. Either the boundary of $B$. glucanolyticus is diffuse and these strains are varieties of $B$. glucanolyticus, or these strains represent members of a closely related species. Isolation and characterization of more of these strains will be necessary to clarify this situation.

The correlation between level of DNA homology to strain S93 ${ }^{\mathrm{T}}$ and pustulan hydrolysis was generally good. However, the three unidentified strains also hydrolyzed pustulan (Table 3), so this test should not be used in isolation to identify strains of $B$. glucanolyticus. There was little homology between DNA from the reference strain of $B$. glucanolyticus and DNAs from other facultatively anaerobic species in the $B$. circulans complex (Table 4). We did not include Bacillus chondroitinus and Bacillus alginolyticus strains in this study because they are strict aerobes. The DNA relatedness data confirm the phenotypic classification which shows that strains of $B$. glucanolyticus are different from other $B$. circulans-like species.

\section{ACKNOWLEDGMENT}

We thank Gesellschaft für Biotechnologische Forschung mbH for a grant for work of relevance to the Deutsche Sammlung von Mikroorganismen und Zellkulturen.

\section{LITERATURE CITED}

1. Borris, R., H. Bäumlein, and J. Hoffmeister. 1985. Expression in Escherichia coli of a cloned $\beta$-glucanase gene from Bacillus amyloliquefaciens. Appl. Microbiol. Biotechnol. 22:63-71.

2. Feinberg, A. P., and B. Vogelstein. 1983. A technique for radiolabelling DNA restriction endonuclease fragments to high specific activity. Anal. Biochem. 132:6-13.

3. Fleet, G. H., and H. J. Phaff. 1974. Lysis of yeast cell walls: glycanases from Bacillus circulans WL-12. J. Bacteriol. 119: 207-219.

4. Gordon, R. E., W. C. Haynes, and C. H.-N. Pang. 1973. The genus Bacillus. Agriculture Handbook no. 427. United States Department of Agriculture, Washington, D.C.

5. Johnson, J. L. 1981. Genetic characterization, p. 450-472. In P. 
Gerhardt, R. G. E. Murray, R. N. Costilow, E. W. Nester W. A. Wood, N. R. Krieg, and G. B. Phillips (ed.), Manual of methods for general bacteriology. American Society for Microbiology, Washington, D.C.

6. Johnson, J. L. 1984. Nucleic acids in bacterial classification, p 8-11. In N. R. Kreig and J. G. Holt (ed.), Bergey's manual of systematic bacteriology, vol. 1. The Williams \& Wilkins Co. Baltimore.

7. Nakamura, L. K. 1984. Bacillus amylolyticus sp. nov., nom. rev., Bacillus lautus sp. nov., nom., rev., Bacillus pabuli sp. nov., nom. rev., and Bacillus validus sp. nov., nom. rev. Int. J. Syst. Bacteriol. 34:224-226.

8. Nakamura, L. K. 1987. Bacillus alginolyticus sp. nov. and Bacillus chondriotinus sp. nov., two alginate-degrading species. Int. J. Syst. Bacteriol. 37:284-286.

9. Nakamura, L. K., and J. Swezey. 1983. Taxonomy of Bacillus circulans Jordan 1890: base composition and reassociation of deoxyribonucleic acid. Int. J. Syst. Bacteriol. 33:46-52.

10. Nakamura, L. K., and J. Swezey. 1983. Deoxyribonucleic acid relatedness of Bacillus circulans Jordan 1890 strains. Int. J. Syst. Bacteriol. 33:703-708.

11. Owen, R. J., and D. Pitcher. 1985. Current methods for estimating DNA base composition and levels of DNA-DNA hybridization, p. 67-93. In M. Goodfellow and D. E. Minnikin (ed.)
Chemical methods in bacterial systematics. Academic Press, Inc. (London), Ltd., London.

12. Priest, F. G. 1977. Extracellular enzyme synthesis in the genus Bacillus. Bacteriol. Rev. 41:711-753.

13. Priest, F. G., and B. Alexander. 1988. A frequency matrix for the probabilistic identification of some bacillt. J. Gen. Microbiol. 134:3011-3018.

14. Priest, F. G., M. Goodfellow, and C. Todd. 1988. A numerical classification of the genus Bacillus. J. Gen. Microbiol. 134: 1847-1882.

15. Robson, L. M., and G. H. Chambliss. 1984. Characterization of the cellulolytic activity of a Bacillus isolate. Appl. Environ. Microbiol. 47:1039-1046.

16. Rodriguez, R. L., and R. C. Tait. 1983. Recombinant DNA techniques: an introduction, p. 162-163. Addison-Wesley Publishing Co., Reading, Mass.

17. Rombouts, F. M., and H. J. Phaff. 1976. Lysis of yeast cell walls. Lytic $\beta-(1 \rightarrow 6)$-glucanases from Bacillus circulans WL12. Eur. J. Biochem. 63:109-120.

18. Seldin, L., and D. Dubnau. 1985. Deoxyribonucleic acid homology among Bacillus polymyxa, Bacillus macerans, Bacillus azotofixans, and other nitrogen-fixing Bacillus strains. Int. J. Syst. Bacteriol. 35:151-154. 